\title{
Living the death of others: the disruption of death in the COVID-19 pandemic
}

Vivendo a morte dos outros: reconfigurações da morte na pandemia da Covid-19

\author{
Marcos Freire de Andrade Neves' \\ https://orcid.org/0000-0002-0752-5788 \\ marcosfan@gmail.com \\ I Freie Universität Berlin - Berlin, Germany \\ Postdoctoral Research Associate
}




\begin{abstract}
On 11 March 2020, the World Health Organization classified the COVID-19 emergency as a pandemic, a decision that was taken following the perception that the virus was both lethal and rapidly spreading. The role played by mortality and contagion in this pandemic narrative, thus, cannot be ignored. On the one hand, contagion acts as a transgressive category that is a main source of socio-political disruptions and a catalyst for new forms of sociality. On the other hand, the effectiveness and persuasiveness of mortality as a quantifiable reality overshadows death as lived experience, obfuscating a profound reorganisation of the ways death is managed and produced through the work of a whole professional segment. Hence, this article explores how the response to the COVID-19 pandemic is reshaping death as lived experience by transgressing categories of existence and reorganising the conditions under which death is managed and produced.
\end{abstract}

Keywords: contagion; data; death; pandemic.

\title{
Resumo
}

Em 11 de março de 2020, a Organização Mundial da Saúde classificou a emergência da Covid-19 em termos de pandemia, uma decisão que seguiu o reconhecimento tanto da letalidade do vírus quanto do seu potencial de transmissibilidade. Nesse contexto, o papel desempenhado pelas categorias de óbito e contágio não pode ser ignorado. De um lado, contágio age como uma categoria transgressora que é fonte de rupturas sócio-políticas e catalisadora de novas formas de sociabilidade. Pelo outro lado, a efetividade e poder de persuasão do óbito enquanto realidade quantificável acaba por ofuscar a morte como experiência vivida. Nesse sentido, o presente artigo explora como a relação entre contágio e mortalidade, bem como a resposta articulada à pandemia, causou uma ruptura na morte enquanto experiência vivida, reorganizando os meios pelos quais ela é gerenciada e produzida através do trabalho de um segmento profissional.

Palavras-chave: contágio; dados; óbito; pandemia. 


\section{Introduction}

On 11 March 2020, during a media briefing at the headquarters of the World Health Organization (WHO) in Geneva, Dr Tedros Adhanom Ghebreyesus, the organisation's Director-General, shared his concerns regarding an increase of COVID-19 cases outside of China. Caused by the virus SARS-CoV-2, the disease caught the WHO's attention on 31 December 2019, when it was first informed about an unusual increase of cases of viral pneumonia in Wuhan, China. During the briefing, he described a situation in which the number of COVID-19 cases outside of China had increased 13-fold and the number of affected countries tripled. The scenario was distressing. "There are now more than 118,000 cases in 114 countries, and 4,291 people have lost their lives", Dr Tedros said. This background of high mortality and infection rates, coupled with "alarming levels of inaction" paved the way for the declaration that this public health emergency was a pandemic, which, he reflected, "is not a word to use lightly or carelessly [and], if misused can cause unreasonable fear, or unjustified acceptance that the fight is over, leading to unnecessary suffering and death" (World Health Organization, 2020).

As Lakoff (2019) argued, the act of classification is vital in allowing the assimilation of specific events into broader administrative frameworks, thus facilitating their legibility and management. In the context of COVID-19, the decision to classify a series of local outbreaks as a pandemic was triggered by the acknowledgement that the virus was both lethal and rapidly spreading, contaminating people across national borders - as illustrated by the data presented by Dr Tedros - and causing a series of social disruptions along the way. As a narrative of public health emergencies, this is not new. We have seen public health emergencies before and we deal with other emergencies of this kind now, such as HIV, tuberculosis, and malaria - albeit, as Caduff (2020, p. 477) noted, these preventable deaths seem to attract less political urgency. "What makes this pandemic unprecedented", he argued, "is not the virus but the response to it" (Caduff, 2020, p. 476).

In this sense, this article is an attempt to understand the impact of the COVID-19 pandemic as a result of the interplay between contagion and mortality as two key factors that justified the pandemic classification. Factors that were able to capture socio-political affects and anxieties that reinforced 
the seriousness of the situation while, at the same time, indicating the urgency of a coordinated response at international level. Following this perspective, contagion and mortality crystallised a specific understanding of the situation and its gravity, while animating discussions on how to appropriately respond to it. The ease and permeability of such metrics in the everyday life under the pandemic, as well as the imaginaries and affects they elicit, made contagion and mortality crystallise the circumstances that justified and led to the act of classification - and, conversely, made them common targets of discourses aimed at delegitimising it.

As governance tools, however, contagion and mortality are translated into quantifiable data, which confer legibility to the realities performed by these tools and facilitate the concoction of organised responses. But the persuasion of data and its effectiveness within administrative frameworks may end up suppressing the very realities they help to describe. To examine this process, this article explores the aftermath of a specific pandemic narrative that revolves around contagion and mortality as animating factors of a political economy of life and death. The implications of this are twofold. On the one hand, contagion acts as a transgressive category that is a main source of socio-political disruptions and a catalyst for new forms of sociality - that is, contagion as a category is both disruptive and generative. On the other hand, the effectiveness and persuasiveness of mortality as a quantifiable reality overshadows death as lived experience, obfuscating a profound reorganisation of the ways death is managed and produced through the work of a whole professional segment. To put it differently, the performativity of death as a quantifiable reality is effective by making opaque the everyday experiences behind it.

Therefore, to explore this narrative is an attempt to shed light on the disruptions of death as lived experience as a result of the interplay between contagion and mortality. Since 2014, over the course of an ongoing research project that seeks to understand the production of death through the work of several mediations, such as medico-legal, economic, and bureaucratic ones, and through technical interventions on the body, I have familiarised myself with death as lived experience and with people whose job it is to live the death of others by helping to produce the dead person (Andrade Neves, 2017; Andrade Neves; Damo, 2016). But despite providing an essential service, their work 
tends to be overlooked in crisis narratives where death is seen as the endpoint, often ignored amidst the intensity of emotions and affects that death usually evokes. In the context of the COVID-19 pandemic, whereas contagion can be seen as a starting point, something that acts to spread and intensify outbreaks, and the control of which would eventually lead to the successful control of the pandemic itself, mortality rates suggest an endpoint of failure in the management of the pandemic. This common narrative, however, not only fails to consider that the individual deaths behind mortality rates are the starting point of a whole new chapter in this pandemic narrative, but also that the way death itself used to be produced through rituals, technical procedures, and negotiations is being profoundly reorganised.

Focusing mostly on the Brazilian context and, more precisely, the city of Porto Alegre and its greater metropolitan area, this article explores how the response to the COVID-19 pandemic is reshaping death as lived experience by transgressing categories of existence and reorganising the conditions under which the dead person can be produced. ${ }^{1}$ Living the death of others, thus, is an allusion to the workings of a professional segment that operates inside a blackbox of death, one that hides the everyday life of people whose job it is to live the death of others while giving centre stage to death as an abstract, depersonalised occurrence. In 2020, during a conversation with Nina, ${ }^{2}$ one of such professionals who live the death of others, she expressed the following: "Our routine changed completely [due to the pandemic], everything's very difficult now". In a certain sense, this article is an effort to fathom Nina's comment by making sense of the circumstances that led to this change in her routine during the pandemic and its implications. While the pandemic has caused disruptions that led directly or indirectly to the death of many people, what follows when death itself is disrupted?

1 This research is based on ongoing fieldwork that, similarly to many other aspects of everyday life, was also disrupted by the pandemic. Owing to the associated limitations, this research draws from previous fieldwork experience and online interviews.

2 Nina has allowed her real name to be used. And although "Nina" is her nickname, she uses it professionally as well. The conversations took place in Portuguese, so the translations are mine. 


\section{From death to mortality}

The act of classification conveys greater visibility to local, geographically scattered events attributed to the virus. In the case of COVID-19, the process of classification in terms of a pandemic took place over the course of three months, from the moment cases of pneumonia with unknown causes were first reported until the identification of the virus and the subsequent classification in March 2020. On 30 January 2020, when only 98 cases of COVID-19 had been identified outside of China (and no deaths), the WHO declared local outbreaks a public health emergency. So it took a little over one month, following a spike in infection cases and the occurrence of deaths associated with COVID-19, for the WHO to declare the pandemic announced during the aforementioned media briefing. Although the virus as a biological entity is at the very core of these events, it is its potential to spread and contaminate that led to its classification as a pandemic - which, according to the WHO (World Health Organization, 2010), is characterised precisely by the "worldwide spread of a new disease". While the act of classification gives greater visibility to geographically dispersed events, it is now necessary to make it legible.

When discussing the impact of different epidemics that took place in Western Europe over the centuries, Foucault resorted to the case of a smallpox epidemic in the 18th Century to address the issue of legibility. In order to understand the epidemic, he argued, it is necessary to know how many people were contaminated, their age, and the disease's mortality rate (Foucault et al., 2004, p. 12). To read the epidemic and to better understand its narrative, it would be necessary to develop quantifiable data that can make the emergency legible and help shape an appropriate response to it. As Sally Engle Merry (2011, p. 85) pointed out, statistical measures and indicators are forms of knowledge that "convey an aura of objective truth and facilitate comparisons", making them effective governance tools. But their effectiveness relies precisely on the reduction of complex social processes to "simple numerical indicators and rankings for purposes of management and control" (Shore; Wright, 2015, p. 22). In this sense, the persuasiveness and effectiveness of governing "by - and through - numbers" is an effect of a process of decontextualisation and reduction from complex to simple (Shore; Wright, 2015, p. 23). And while it may facilitate numerical comparison and the sharing of information, this 
aura of objectivity often conceals a politics of numbers within which such data can be formulated.

For instance, the Instituto Pereira Passos, in Rio de Janeiro, developed an online panel to provide information regarding the COVID-19 pandemic. In August 2020, the panel was showing two divergent mortality data. The first information, formulated by the Federal Ministry of Health, counted 9,634 COVID-deaths in the city of Rio de Janeiro; according to the city administration, however, the city had 4,114 deaths in the same period. The formulation of two contradictory data to represent the same empirical reality was the aftermath of a change in methodology: while the data were initially based on the number of death certificates indicating suspicion of COVID-19, the new methodology counted only the number of burials stating COVID-19 as the cause of death. In a context of limited testing and delayed results, there were more suspected cases than certified ones - and the city administration went with the latter methodology.

When this change of methodology was first introduced, the number of deaths in the city of Rio de Janeiro fell from 2,978 to 1,801, a difference of 1,177 cases. Rather than being objective representations of reality, numbers are methodological choices that need to be contextualised and understood, as Desrosières (1998, p. 7) argued, through the tension between claims to objectivity and universality and "the world of action". Numbers are means to express and to make exist (Desrosières; Kott, 2005); they are means to make visible and to shape a specific reality, not just a representation of one. The politics of numbers during the COVID-19 pandemic in Brazil was also made clear by comments made by state authorities, including president Jair Bolsonaro. In March 2020, Bolsonaro complained about high mortality numbers by saying he did not believe "these numbers" (Fernandes, 2020), accusing states of replacing unknown causes of death with coronavirus in death certificates: "This issue of numbers leave many people doubting", he said, "did they die of COVID-19 or with COVID-19?" (Marcello, 2020). His remarks were quickly followed by a Ministry of Health official, who voiced his wish to have "more real data", since "what we have today is fanciful and manipulated" (Megale, 2020).

While governing by numbers is a constitutive feature of our times (Shore; Wright, 2015, p. 22), it conveys a false perception of objectivity that blurs the understanding of the politics behind it. That is, it enables the legibility 
of a certain reality by decontextualising and depersonalising the lived, everyday experiences on which the numbers are based. This eclipsing of the personal and the person in the context of a process that reduces death to mortality ends up forming a blackbox of death, in which the abstract phenomena casts a shadow over the processes that produced it. Fundamentally, this blackboxing (Latour, 1999) of death attracts attention to mortality rates while obfuscating radical changes in the way specific deaths are being produced and managed on the ground level. In this sense, whereas the reduction of death into mortality encapsulates lived experience inside an abstract category due to the persuasion of absolute numbers, the question of what is happening inside this box remains.

In April 2020, due to fears of contagion amidst the first wave of the COVID-19 pandemic in Porto Alegre, a court order prohibited all funerary rites directly related to COVID-19 - or suspicion thereof - in the state of Rio Grande do Sul (Kepler, 2020). This decision, which also suspended the undertaking of embalming procedures in the state, was ultimately modified in August 2020, when the mayor of Porto Alegre issued an executive order (Porto Alegre, 2020) easing such restrictions and allowing funerary rites to take place past the infection window. On the ground level, such changes, coupled with fears of contagion, completely altered the day-to-day practice of funeral homes, preventing the preparation of bodies, imposing a distance between agents and clients, and restricting the possibility of funerary rites and, by extension, affecting the range of services that can be provided.

\section{Contagion as transgression}

In 1996, Porto Alegre, a relatively large city of some 1.5 million people in southern Brazil, passed new legislation to regulate the city's funerary services. This legislation was an attempt to reorganise what was then seen as an unprofessional and rather predatory industry that walked, and often tripped over, a fine line between emotion and money (Andrade Neves; Damo, 2016). As providers of essential services, the funerary sector falls under the responsibility of municipal administrations. They are responsible for laying out clear rules for the sector and for defining the actors involved - for instance, 
as of 2020 , there were 22 funeral homes authorised to operate within the city limits. ${ }^{3}$ By passing legislation to regulate the funerary services, the goal was to provide a clear blueprint of what products and services needed to be offered, establishing common rules and procedures to be followed by all 22 local funeral homes.

The funerary sector goes beyond funeral homes, comprising also cemeteries, crematories, and local oversight agencies. Whenever a death is reported within city limits, the actors involved in the funerary sector are responsible for coordinating the work of several mediations that, on the one hand, make death a legal reality and, on the other hand, produce the body that will take part in funerary rites. These mediations, however, are not a given. In 2014, when I first started doing fieldwork in a funeral home in Porto Alegre, I followed the circulation of bodies from the moment their deaths were reported until their final destination, usually burial or cremation. By following them, I was able to map out the different mediations and actors involved in each individual death. It is precisely the outcome of their work that I defined elsewhere as the dead person (Andrade Neves, 2017), a specific form of personhood that is encapsulated by different legal protections and challenges simple applications of binaries such as life/death, people/thing, and animated/inert.

Several anthropological accounts have shown how categories of existence like life and death defy common assumptions or easy applications, being often transgressed or reorganised. This can be seen in several contexts, such as in beating-heart cadavers as the result of the interplay between brain death and organ transplantation (Agamben, 1998; Lock, 1996, 2002; Roach, 2003; Scheper Hughes, 2000) or in attempts to rethink life and death outside the constraints of anthropocentric approaches (Chen, 2012; Kohn, 2013; Tsing, 2015). When it comes to the everyday life production of death, such categories of existence relies on a set of interactions and negotiations that makes a biological occurrence into a legal reality - a process that, as Medeiros (2020) described it, kills the dead. By following the circulation of dead bodies in Porto Alegre, I was able

3 There are 22 local funeral homes authorised to operate in Porto Alegre. Also, 11 funeral homes from the greater metropolitan area are authorised to offer limited services within city limits ( 24 services per year). 
to identify these processes and witness their negotiations, including emotional and economic ones (Andrade Neves; Damo, 2016). Among such processes, however, embalming stands out.

Despite not being a legal requirement in most cases of death, embalming is performed on almost every dead body under the care of the funeral home where I conducted most of my fieldwork. This technical intervention in the body, which delays decomposition by replacing body fluids with chemicals such as formaldehyde, is one of the most common services provided by funeral homes, as it fundamentally produces the body that will be displayed in funerary rites, conferring a 'natural' appearance and colour to it. But this procedure is also invasive, requiring personal protective equipment (PPE) due to the possible spilling of fluids and the vaporisation of toxic chemicals - which have the potential to "directly implicate the vulnerability of a living body" (Chen, 2012, p. 203). When I started my fieldwork, João, ${ }^{4}$ a funeral director, would often tease me by repeatedly saying that today would be the day I would finally witness an embalming procedure. While death as an affective image is a constant presence in funeral homes, it is during this procedure that the contact between living and dead bodies are the closest, raising fears of toxicity and contagion that require the living to wear protective gear.

Toxicity, Nading (2020, p. 209-210) suggested, is elusive, as it is not a characteristic of individual substances, but rather the result of contingent encounters "among beings, systems, and things". Along these lines, the contingencies of the funeral home place living and dead bodies in a close, chemically-mediated contact, which requires protection to minimise the risk of contamination and, depending on the cause of death, avoid contagion. But as a consequence of the COVID-19 pandemic, coupled with the invasiveness of embalming, such contingencies were reorganised. "Everything changed in relation to precaution", Nina tells me. As part of her work in funeral homes, Nina is a professional embalmer who often travels to other cities to offer courses on embalming. "The PPE we used to wear is now obsolete and we have to use another kind, an overall and things that we didn't used to use in the lab before". But even with new protective equipment, her routine changed abruptly: "We no longer can 
prepare, ${ }^{5}$ so for non-COVID cases we use one kind of PPE and for COVID cases we have to use this overall and many other things to collect the body".

The COVID-19 pandemic reorganised the contingencies of such encounters by highlighting the risks associated with contagion and, as a consequence, impacting directly on the possibility of close encounters between dead and living bodies. This reorganisation impacted not only the working routine of funerary professionals, but also the experience of death from the perspective of family members. According to Nina, the new contingencies of funerary rites are leading to suffering. "People are suffering more", she tells me, "the way burials are being carried out is very unpleasant. The fact that you cannot view the body, say goodbye, is bringing a lot of pain and suffering". Similar reorganisations are also taking place outside of the funerary sector, such as hospitals and Intensive Care Units, where a political and moral economy of life and death is redefining doctor-patient relationships (Colas, 2020) or physicians' embodied practices (Block, 2020).

In 2016, Elizabeth Povinelli raised the question of whether a long-standing focus on certain figures of biopolitics ended up obfuscating new problems that would now be central to our understanding of contemporary power. One such manifestation would be viruses. Although not new, viruses are located in the centre of a series of critical events, such as epidemics and pandemics, that were able to reorganise social relations and generate new subjectivities (Keck; Kelly; Lynteris, 2019, p. 3), as well as radically alter our ways of being in the world. In the COVID-19 pandemic, several facets of socio-political disruptions have already been explored, such as militarisation (Levine; Manderson, 2020), food production (Haysom, 2020), and socio-economic inequality (Kopper, 2020). And the role played by contagion in pandemic narratives is key to understanding such disruptions.

"The dark side of modernisation, medical and political progress", epidemics have been used to justify "policies of segregation, resettlement, quarantine, and population surveillance" (Keck; Kelly; Lynteris, 2019, p. 2). In this sense, as Caduff (2020, p. 480) noticed, pandemic time can be an "auspicious time

5 Prepare, or preparação, is an emic term to describe the embalming of a body. It is common to hear that the body is being "prepared". 
for all kinds of political projects". This can be seen, for instance, in the politics of leprosy control in many countries, in which the lack of knowledge and the fear of contagion led to the establishment of colonies that crystallised all of the aforementioned elements of segregation and health surveillance (Fonseca, 2020; Maricato, 2019; White, 2003). If, as Povinelli suggested, the virus is an important prism through which we can better understand contemporary power, it is through its circulation, via contagion, and the responses it triggers that we can grasp its impact on regimes of life and death and on moral economies associated with them (Chen, 2012, p. 6; Fassin, 2018).

In a roundtable to discuss the category of contagion, Jih-Fei Cheng proposed thinking about contagion as "inevitable transgressions of our artificially given discrete categories of existence" (Lin; Chen; Cheng, 2017, p. 1). By inscribing the virus, an entity that itself fails the so-called tests of life, as an active participant in regimes of life and death, its contagious quality ends up transgressing such regimes by redistributing life and death within the nexus of socio-economic, demographic, and racial criteria, among others. In this sense, contagion is a transgressive category that gives motion to a redistribution of life and death. In Porto Alegre, saving disasters or critical events, the number of deaths tends to be stable. In 2020 , there were 21,349 deaths that were distributed among local funeral homes. ${ }^{6}$ Within this universe, João's funeral home - where I had my first contact with embalming procedures - was responsible for managing about $5 \%$ of such deaths. In the first five months of 2020 , from January to May, this funeral home managed on average 64 deaths per month. In the final seven months, from June to December, the average rose to 104. This trend can also be seen in the whole city, where the monthly average of deaths rose from 1553 in the first five months to 1940 in the final seven months.

The COVID-19 pandemic has also impacted where people died. In the final seven months of 2020, from June to December, there was a $31 \%$ increase in the number of deaths inside local hospitals in comparison to the first five months, from January to May. Similarly, the number of deaths taking place inside private homes rose $48 \%$ in the same period, while the number of deaths due to

6 Based on information provided by the Central de Atendimento Funerário (CAF), the municipal agency responsible to oversee the city's funerary services. 
external causes went down $14 \%{ }^{7}$ Referring to her experience during the first wave of the pandemic, in the course of our first conversation in April 2020, Nina said: "The number of deaths is actually lower in comparison to last year, since because of the pandemic people are not leaving their homes; there are less accidents, less natural deaths... I don't know what's happening, but the number is lower. But we have an exponential increase in the number of corona deaths". At that time, the number of deaths in the city was relatively stable, a scenario that changed from June onwards.

Besides an effect on the overall number of deaths, the coupling of virus and contagion in the context of the COVID-19 pandemic led to a rearrangement of the kinds of death people were dying - and, as a result, the kinds of death Nina had to experience in her work routine. When we first talked, during the first wave of COVID-19, the radical change in Nina's routine was an effect of contagion: on the one hand, the risks and fears associated with contagion prevented the carrying out of embalming procedures and led to new protective measures that hindered the contact between living and dead bodies. On the other hand, it altered the kinds of death she had to live.

\section{Final remarks}

"People are not being able to say goodbye; we stopped selling funerals to sell caskets. That's how things are", Nina told me. "It's been very complicated; people are not even allowed to say goodbye to their relatives". But even though these changes affected her work directly, Nina was one of the professionals who defended the suspension of funerary rites during the pandemic, acknowledging that these events may cause large gatherings of people, many of whom may be old-aged. The interplay of contagion and mortality during the COVID-19 pandemic is reshaping death by radically altering the range of possibilities for the occurrence of funerary rites and by preventing the preparation of the dead body on account of risk.

7 By external causes I mean deaths that fall under the remit of the local coroner's office. These are mostly deaths that need to be investigated for being deemed violent or suspicious. 
Recently, Giorgio Agamben voiced his concern on the transformation of death during the COVID-19 pandemic, questioning how we accepted, "in the name of a risk that we couldn't even quantify", that people should die alone and that "their corpses should be burned without a funeral" (Caldwell, 2020). Going back to Caduff's assertion, what is new in this current global health emergency is not the virus itself, but our response to it - which "pushed the world into a space of fragility and uncertainty" (Caduff, 2020, p. 476) that opened up the possibility for a profound, and possibly long-lasting reorganisation of life and death. Agamben's question, although posed in the context of an attempt to delegitimise social distancing measures by framing them as a pretext for the withdrawal of rights, encapsulates the intensity of the impact that the COVID-19 pandemic had not only in our ways of living and being in the world, but also of dying in it.

There is a vital link between contagion and mortality as categories that animate, that give motion to the COVID-19 pandemic, and that shape the response to it. On the one hand, contagion acts as a transgressive category that reorganises a political economy of life and death by creating disruptions and, as such, new forms of living and of dying. On the other hand, mortality as a quantifiable reality is an essential governance tool, but whose efficacy relies on a process of decontextualisation that erases the person and the personal, and favours the abstract and the general. For Nina, as well as to many others in her line of work, death is not abstract, quantifiable data, but an everyday experience, something able to elicit effects and generate relations. While contagion has a direct effect on her work as embalmer, the power of persuasion of mortality ends up clouding significant transformations in the ways death are lived and ritualised.

As a critical event, the pandemic did not just affect Nina's own way of life, but also the ways she experienced the death of others. Death itself was disrupted as new social and political contingencies of the pandemic unfolded. This article, thus, was an attempt to counter, and perhaps open, a blackbox of death by exploring the transformations and reorganisations that are taking place inside of it, transformations with which we are going to have to live (and die) for some time to come. 


\section{References}

AGAMBEN, G. Sovereign power and bare life. Stanford: Stanford University Press, 1998.

ANDRADE NEVES, M. Por onde vivem os mortos: o processo de fabricação da morte e da pessoa morta no complexo funerário de Porto Alegre. Porto Alegre: Editora da UFRGS, 2017.

ANDRADE NEVES, M.; DAMO, A. S. Dinheiro, emoção e agência: uma etnografia no mercado funerário de Porto Alegre. Mana, Rio de Janeiro, v. 22, n. 1, p. 7-36, 2016.

BLOCK, E. Clinicians on the frontlines of the COVID-19 pandemic. Anthropology in Action, New York, v. 27, n. 2, p. 63, 2020.

CADUFF, C. What went wrong: Corona and the world after the full stop. Medical Anthropology Quarterly, Arlington, v. 34, n. 4, p. 467-487, 2020.

CALDWELL, C. Meet the philosopher who is trying to explain the pandemic. The New York Times, New York, 21 Aug. 2020. Available at: https://www.nytimes. com/2020/08/21/opinion/sunday/giorgio-agamben-philosophy-coronavirus.html. Access: 30 Aug. 2020.

CHEN, M. Y. Animacies: biopolitics, racial mattering, and queer affect. Durham: Duke University Press, 2012.

COLAS, K. An explorarion of the physician-patient relationship during the COVID19 pandemic. Anthropology in Action, New York, v. 27, n. 2, p. 20, 2020.

DESROSIÈRES, A. The politics of large numbers: a history of statistical reasoning. Cambridge: Harvard University Press, 1998.

DESROSIÈRES, A.; KOTT, S. Quantifier. Genèses, [s. l.], v. 58, n. 1, p. 2-3, 2005.

ENGLE MERRY, S. Measuring the world: indicators, human rights, and global governance: with CA comment by John M. Conley. Current Anthropology, Chicago, v. 52, n. S3, p. S83-S95, 2011.

FASSIN, D. Life: a critical user's manual. Cambridge: Polity, 2018.

FERNANDES, A. Bolsonaro chama Doria de "papagaio de auditório" e duvida de mortes em SP. Correio Braziliense, Brasília, 27 mar. 2020. Available at: https://www.correiobraziliense.com.br/app/noticia/politica/2020/03/27/interna_politica,840813/ bolsonaro-chama-doria-de-papagaio-de-auditorio-e-duvida-de-mortes-em.shtml. Access: 30 Aug. 2020. 
FONSECA, C. Evidências, experiências e endemias: fatos científicos nas políticas de combate à hanseníase. Anuário Antropológico, Brasília, v. 45, n. 2, p. 164-187, 2020.

FOUCAULT, M. et al. Sécurité, territoire, population: cours au Collège de France, 19771978. Paris: Seuil: Gallimard, 2004.

HAYSOM, G. When "slow violence" collides with visceral hunger - COVID-19 and the current and future food system of Cape Town, South Africa. In: MEDIZINETHNOLOGIE: Körper, Gesundheit und Heilung in einer globalisierten Welt. [S. l.]: Arbeitsgruppe Medical Anthropology, 2020. Available at: https://www.medizinethnologie. net/when-slow-violence-collides-with-visceral-hunger-south-africa-witnessing-corona/. Access: 30 Aug. 2020.

KECK, F.; KELLY, A. H.; LYNTERIS, C. Introduction: the anthropology of epidemics. In: KELLY, A. H.; KECK, F.; LYNTERIS, C. (ed.). The anthropology of epidemics. London: Routledge, 2019. p. 1-24.

KEPLER, G. Sindicato das funerárias do RS garante na Justiça proibição de velórios por óbitos de Covid-19. Correio do Povo, Porto Alegre, 8 abr. 2020. Available at: https://www.correiodopovo.com.br/not\%C3\%ADcias/geral/sindicato-das-funer\%C3\%Alrias-do-rs-garante-na-justi\%C3\%A7a-proibi\%C3\%A7\%C3\%A3o-devel\%C3\%B3rios-por-\%C3\%B3bitos-de-covid-19-1.411239. Access: 30 Aug. 2020.

KOHN, E. How forests think: toward an anthropology beyond the human. Berkeley: University of California Press, 2013.

KOPPER, M. Silent encroachments: counting and grappling with COVID-19 in unequal Brazil. In: MEDIZINETHNOLOGIE: Körper, Gesundheit und Heilung in einer globalisierten Welt. [S. l.]: Arbeitsgruppe Medical Anthropology, 2020. Available at: https://www.medizinethnologie.net/silent-encroachments/. Access: 30 Aug. 2020.

LAKOFF, A. What is an epidemic emergency? In: KELLY, A. H.; KECK, F.; LYNTERIS, C. (ed.). The anthropology of epidemics. London: Routledge, 2019. p. 59-69.

LATOUR, B. Pandora's hope: essays on the reality of science studies. Cambridge: Harvard University Press, 1999.

LEVINE, S.; MANDERSON, L. The militarisation of the COVID-19 response in South Africa. In: MEDIZINETHNOLOGIE: Körper, Gesundheit und Heilung in einer globalisierten Welt. [S. l.]: Arbeitsgruppe Medical Anthropology, 2020. Available at: https:// www.medizinethnologie.net/the-militarisation-of-the-covid-19-response-in-southafrica/. Access: 30 Aug. 2020. 
LIN, C.; CHEN, M. Y.; CHENG, J.-F. What is contagion?: a roundtable. Sublevel, [s. l.], n. 1, 2017. Avalable at: https://sublevelmagazine.com/issues/contagion/what-is-contagion. Access: 30 Aug. 2020.

LOCK, M. Death in technological time: locating the end of meaningful life. Medical Anthropology Quarterly, Arlington, v. 10, n. 4, p. 575-600, 1996.

LOCK, M. Twice dead: organ transplants and the reinvention of death. Berkeley: University of California Press, 2002.

MARCELLO, M. C. Bolsonaro critica OMS e diz que ninguém quer maquiar númeras da pandemia no Brasil. Reuters, [s. l.], 18 jun. 2020. Available at: https://mobile.reuters.com/article/amp/idLTAKBN23P3SO?edition-redirect=in. Access: 30 Aug. 2020.

MARICATO, G. História sem fim: sobre dobras e políticas ontológicas de um 'mundo sem hanseníase'. 2019. Tese (Doutorado em Antropologia Social) - Instituto de Filosofia e Ciências Humanas, Universidade Federal do Rio Grande do Sul, Porto Alegre, 2019.

MEDEIROS, F. Matar o morto: uma etnografia do Instituto Médico-Legal do Rio de Janeiro. Niterói: EDUFF, 2020. (Coleção Antropologia e ciência política, v. 57).

MEGALE, B. Ministério da Saúde vai recontar mortos pela covid-19 porque diz ver "dados fantasiosos". O Globo, Rio de Janeiro, 5 jun. 2020. Available at: https://blogs. oglobo.globo.com/bela-megale/post/ministerio-da-saude-vai-recontar-mortos-pelacovid-19-porque-diz-ver-dados-fantasiosos.html. Access: 30 Aug. 2020.

NADING, A. M. Living in a toxic world. Annual Review of Anthropology, Palo Alto, v. 49, n. 1, p. 209-224, 2020.

PORTO ALEGRE. Decreto $n^{\circ} 20.709$, de 27 de agosto de 2020. Altera o $\S 3^{\circ}$ no art. 12 e o $\S$ $2^{\circ}$ no art. 18; inclui o $\$ 3^{\circ}$-Ano art. 12 , o $\$ 2^{\circ}$-A no art. 18 e o Anexo I e revoga os incs. I e II do $\S 3^{\circ}$ do art. 12 do Decreto $\mathrm{n}^{\circ} 20.625$, de 23 de junho de 2020 , para alterar funcionamento das feiras livres. Porto Alegre: PMPA, 2020. Available at: http://dopaonlineupload.procempa.com.br/dopaonlineupload/3588_ce_298701_1.pdf. Access:30 Aug. 2020.

ROACH, M. Stiff: the curious lives of human cadavers. New York: W.W. Norton \& Co., 2003.

SCHEPER HUGHES, N. The global traffic in human organs. Current Anthropology, Chicago, v. 41, n. 2, p. 191-224, 2000.

SHORE, C.; WRIGHT, S. Governing by numbers: audit culture, rankings and the new world order. Social Anthropology, Hoboken, v. 23, n. 1, p. 22-28, 2015. 
TSING, A. L. The mushroom at the end of the world: on the possibility of life in capitalist ruins. Princeton: Princeton University Press, 2015.

WHITE, C. Carville and Curupaiti: experiences of confinement and community. História, Ciências, Saúde-Manguinhos, Rio de Janeiro, v. 10, supl. 1, p. 123-141, 2003.

WORLD HEALTH ORGANIZATION. What is a pandemic?. [S. l.]: WHO, 24 Feb. 2010. Available at: https://www.who.int/csr/disease/swineflu/frequently_asked_questions/pandemic/en/. Access: 30 Aug. 2020.

WORLD HEALTH ORGANIZATION. WHO Director-General's opening remarks at the media briefing on COVID-19 - 11 March 2020. [S. l.]: WHO, 11 Mar. 2020. Available at: https://www.who.int/director-general/speeches/detail/who-director-general-sopening-remarks-at-the-media-briefing-on-covid-19---11-march-2020. Access: 30 Aug. 2020.

Recebido: 31/08/2020 Aceito: 20/01/2021 | Received: 8/31/2020 Accepted: 1/20/2021 